\title{
ANALISIS TANDA PADA KARYA DESAIN KOMUNIKASI VISUAL
}

\author{
Ernawati \\ Program Studi Desain Komunikasi Visual \\ Fakultas Teknik, Universitas Maarif hasyim Latif \\ e-mail : ernawati@dosen.umaha.ac.id \\ Diterima : 26 Maret 2019. Disetujui : 9 Mei 2019. Dipublikasikan : 30 Juni 2019 \\ CC) (7) $\begin{aligned} & \text { O2019 - DESKOVI Universitas Maarif Hasyim Latif. Ini adalah artikel dengan akses } \\ & \text { terbuka di bawah lisensi CC BY } 4.0 \text { (https://creativecommons.org/licenses/by/4.0/) }\end{aligned}$
}

\begin{abstract}
ABSTRAK
Tujuan dari penelitian ini adalah untuk mengetahui makna denotasi dan konotasi pada tanda visual karya desain komunikasi visual. Metode yang digunakan dalam penelitian ini adalah metode semiotika dengan pendekatan semiotika Roland Barthes. Hasil dari penelitian ini, menunjukan bahwa Karya desain visual memiliki tanda berbentuk verbal (bahasa) dan visual, serta menunjukan bahwa penyajian karya desain komunikasi visual mengandung tanda sebagai ikon untuk menyampaikan pesan dalam sistem non kebahasaan yaitu bentuk visual yang mendukung sistem verbal dengan tanda bersifat peniruan kebentukansesuai kenyataan (similrarity). Semiotika sebagai metode analisis tanda guna membedah karya desain komunikasi visual layak untuk disikapi dengan menerapkannya secara proaktif sesuai konteksnya.
\end{abstract}

Kata kunci: Semiotika, Tanda, Karya, Makna

\begin{abstract}
The purpose of this research is to know the meaning of denotation and connotation in visual sign of visual communication design. This research uses semiotic method with Roland Barthes's semiotic approach. Result of this reseach, show that visual design art has a verbal (linguistic) and visual sign, also show that presentation of visual communication design art containing signs as an icon to deliver messages in non-linguistic system is a visual form that support verbal system with signs of impersonation according to reality (similrarity). Semiotic as a sign analysis method to operate visual communication design art are appropriate to be addressed by applying them proactively according to the context.
\end{abstract}

Keyword: Semiotic, Sign, Art Work, Meaning

\section{PENDAHULUAN}

Semua makhluk hidup salah satunya manusia dalam rangka memenuhi kebutuhan hidupnya perlu berkomunikasi dengan makhluk hidup yang lainnya. Penyampaian pesan tersebut memerlukan sarana dalam proses penyampaiannya, baik secara verbal maupun nonverbal/visual. Oleh karena itu manusia menciptakan tanda-tanda yang dapat ditangkap oleh indera, dan menginterpretasikan makna yang dimuat tanda tersebut. Berangkat dari tanda sederhana sampai yang memiliki tingkat kesulitan tertentu untuk memahaminya, tentu manusia menggunakan sistem tertentu untuk dapat memahaminya. Gambar merupakan wujud lambang dari bahasa visual yang mengandung unsur-unsur visual yang dapat dilihat oleh indra dan menyampaikan pesan tertentu melalui visual yang dihadirkan.

Daya sensitifitas setiap perupa sebagai pencipta karya dalam merespon situasi lingkungan memiliki perbedaan, yang disampaikan melalui proses kreatif dengan bukti wujud berupa karya visual. Karya perupa merupakan representasi terhadap dunia di luar perupa maupun kenyataan yang bersentuhan dengan diri perupa yang menimbulkan tanggapan, sehingga lahirlah karya visual. Dalam rangka mengetahui proses kreatifitas dan sensitifitas mahasiswa dalam berkarya, mengkaji karya desain komunikasi visual berdasarkan makna denotasi yang terlihat oleh

indra dan makna konotasi seberapa jauh pesan yang disampaikan menjadi salah satu alternatif yang perlu untuk dilakukan. Dalam melaksanakan hal tersebut, perlu memiliki kepekaan teori sebagai pisau bedah pemaparan. Salah satu teori yang dapat digunakan yaitu bidang ilmu semiotika.

Posisi semiotika pada proses penulisan sebagai metode pendekatan teoritis, sekaligus berorientasi terhadap tanda-tanda visual yang dihadirkan sebagai tekstual dan makna-makna didalamnya sebagai kontekstual yang memuat pesan yang ingin disampaikan oleh pencipta karya. Pencipta karya pada kasus ini mahasiswa prodi Desain Komunikasi Visual, 
fakultas Teknik Universitas Maarif Hasyim Latif. Selain itu semiotika sebagai pendekatan teori dan metode analisis yang dapat digunakan pula oleh pengkaji karya visual baik seni rupa maupun desain.

Lebih jauh lagi analisis karya ini dilakukan dalam rangka ikut berkontribusi memberikan pemahaman di lingkungan akademis akan pentingnya peran semiotika dalam bidang visual (seni rupa dan desain) dan bagaimana sistem tanda bekerja dalam karya. Mengingat ada berbagai jenis semiotika, penulis lebih kepada semiotika analitik dengan menganalisis sistem tanda meliputi obyek, sistem dan makna. Pendekatan teori Roland Barthes digunakan untuk membedah karya mahasiswa supaya dapat mengetahui tanda-tanda yang digunakannya melalui analisis secara denotasi dan konotasi.

\section{METODE PENELITIAN}

Metode pada penelitian ini menggunakan metode kualitatif, dengan pendekatan analisis semiotik. Analisis semiotik digunakan dalam upaya mengungkap makna kontekstual dari tekstual yang dihadirkan mealui visual. Pada teori semiotika dikenal dengan istilah makna denotasi dan makna konotasi dari Roland Barthes. Fokus kajian pada penelitian ini adalah analisis visual pada beberapa karya semester enam prodi Desain Komunikasi Visual (DKV).

\section{Teknik Pengumpulan Data}

a. Observasi, yaitu melibatkan diri langsung dengan objek yang diteliti yaitu karya mahasiswa. Hal ini dilakukan supaya peneliti sebagai instrumen utama (key instrument) dapat merasakan objek yang diteliti dan dapat memberikan penilaian

b. Dokumentasi, yaitu pengumpulan data dan informasi tentang objek penelitian. Dokumentasi ini dilakukan dengan mengambil data berupa gambar karya.

c. Studi Literatur

d. Mencari dan mengumpulkan literatur yang berhubungan dengan ilmu semiotika, poster, logo guna relevansi sumber dalam rangka penafsiran/interpretasi karya. Selain literatur pokok tentang semiotika, penulis juga menggunakan pustaka pendukung seperti kamus diksi rupa, kamus bahasa indonesia, dan sumber webtografi/internet.

\section{Analisis Data}

Guna mengungkap data tersebut, peneliti melakukan langkah analisis model semiotika Roland Barthes melalui dua tahap signifikasi. Tahapan tersebut terdiri atas tahap signifikasi denotasi dan tahap signifikasi konotasi. Pada tahap denotasi peneliti fokus pada visualisasi yang terindera berupa realitas eksternal yang lebih nyata dekat dengan tanda visual. Pada tahap berikutnya dilanjutkan dengan tahap konotasi yang melibatkan penafsir pada aspek nilai kontekstual yang ingin disampaikan oleh karya yang disajikan. Dalam menghasilkan interpretasi atas karya dilakukan analisis denotasi dan konotasi berdasarkan bagan analisis Roland Barthes sesuai pada Semiotika Visual (Budiman: 39).

\begin{tabular}{|c|c|c|}
\hline $\begin{array}{l}\text { 1. Signifi } \\
\text { er }\end{array}$ & 2. Signified & \\
\hline & $\begin{array}{l}\text { 3. Sign } \\
\text { I. Signifier }\end{array}$ & II.Signified \\
\hline \multicolumn{3}{|c|}{ III.Sign } \\
\hline
\end{tabular}

\section{PEMBAHASAN}

\section{Tanda Menurut Roland Barthes}

Roland Barthes merupakan salah satu filsuf yang berperan penting dalam bidang semiotika. Roland Barthes tokoh semiotika yang mengembangkan teori dari pemahaman semiotika yang dibentuk oleh Ferdinand de Saussure, ahli dalam bidang linguistik yang menyatakan tanda berdasarkan konsep semiotika sampai pada tingkat denotasi. Pada tingkatan saussuran tanda (sign), muatan produksi makan hanya sebatas pada tatanan penggambaran tanda dan petanda. Denotasi merupakan pesan harfiah melalui citra yang berfungsi untuk menaturalkan pesan simbolik. Sementara pesan tanda atau simbol tesebut merupakan konotasi yang keberadaannya didasarkan atas kode budaya tertentu. Kenyataan tersebut ketika dihubungkan dengan visual hanya menghasilkan hal yang terlihat dengan indera mata dan label nama dari visual tanda yang dihadirkan. Dalam memaparkan representasi visual, bahasa indera yang sebatas tekstual tidak dapat mengungkap lebih mendalam tentang makna termuat dalam konseptual yang ingin dikomunikasikan pencipta seni maupun desain dalam karya yang dihadirkan. Sementara dilain pihak konsep merupakan hal yang krusial dalam suatu karya, baik seni rupa maupun desain.

Tanda-tanda dikatakan pula sebagai kode. Kode didefinisikan oleh Umberto Eco"...aturan yang menghasilkan tanda-tanda sebagai penampilan konkritnya di dalam hubungan komunikasi (Yasraf A.Piliang: 351). Kode-kode tersebut dikelompokan dalam kisi-kisi kode. Roland Barthes mengelompokan kode-kode tersebut menjadi lima, yakni kode hermeneutik, kode semantik, kode simbolik, kode narasi dan kode kebudayaan.

Semiotika berdasarkan pandangan Roland Barthes tentang denotasi dan konotasi mampu berperan dalam pisau bedah pemaparan makna dalam visual. Roland Barthes memaparkan pendekatan semiotika yang tertuju kepada tuturan yang dikenal dengan mitos (Budiman: 38). Barthes berpendapat bahwa bahasa memerlukan kondisi tertentu untuk menjadi mitos, yakni secara semiotik ditandai dengan hadirnya tataran signifikasi yang disebut semiologis tigkat kedua. Proses signifikasi berlapis ganda ini digambarkan melalui konseptual yang lebih familiar dengan sebutan denotasi dan konotasi. 
Denotasi merupakan tingkat pertandaan yang menjelaskan hubungan antara penanda dan petanda, atau antara tanda dan rujukannya pada realitas guna menghasilkan makna ekplisit yang bersifat langsung dan pasti.Denotasi termasuk tingkatan pertandaan yang cenderung konvensional karena makna pada elemenelemen tanda mampu disepakati secara sosial. Konotasi pada tingkat pertandaan menjelaskan hubungan penanda dan petanda, yang didalamnya beroperasi makna yang lebih implisit, bersifat tidak langsung dan tidak pasti sehingga membuka kemungkinan untuk berbagai penafsiran. Pada tahap penafsiran tersebut menciptakan makna-makna berlafis yang terbentuk ketika dikaitkan dengan berbagai aspek psikologis, baik perasaan, emosi maupun keyakinan yang disebut dengan makna konotatif.

Pada tataran konotasilah keniscayaan tanda mulai bekerja dan berinteraksi ketika bertemu dengan perasaan, emosi dan nilai-nilai kultural yang dimuatnya. Pada tataran konotasi merupakan suatu sistem yang menyatukan tanda, petanda beserta proses yang menyatukan keduanya (signifikasi) sehingga menyampaikan muatan nilai atau makna.

\section{Antara Karya dan Tanda}

Pembahasan karya grafis atau Desain Komunikasi Visual dengan kajian semiotika akan menggunakan teori Roland Barthes untuk melihat kode. Kode tersebut meliputi kode hermeneutik, kode semantik, kode narasi dan kode kebudayaan. Aspek lain yang akan dikaji dan dianalisis yang merupakan poin penting yait melihat makna denotatif dan makna konotatif yang merupakan teori Roland Barthes berdasarkan pengembangan dari teori Saussure.

Berikut ini pembahasan enam karya desain komunikasi visual dengan menggunakan metode semiotika visual Roland Barthes:

\section{a. Tanda pada Poster untuk Kesadaran Masyarakat terhadap Bencana Alam}

\section{Makna Denotasi}

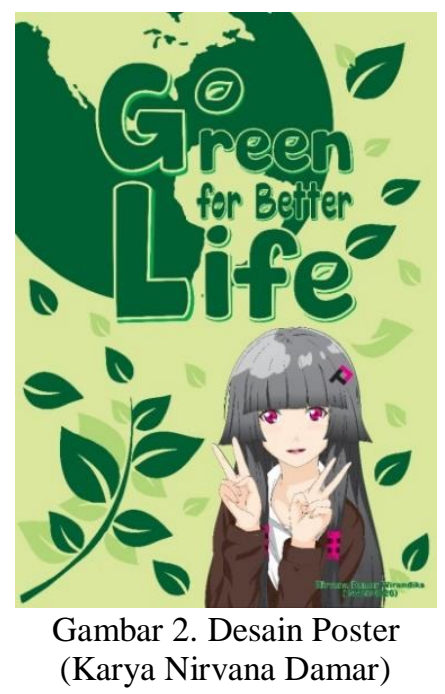

Secara visual karya poster ini terlihat didominasi dengan warna hijau. Ilustrasi pada poster merupakan seorang remaja terseyum mengajak dan merasakan dampak positif dari penghijauan. Diatasnya terdapat gambar bumi dan dedaunan. Poster ini menggambarkan tentang kondisi jika kita bisa menjaga dan melakukan penghijauan. Suasana menjadi lebih baik jika kita semua selalu melakukan penghijauan agar kita dan generasi seterusnya dapat tersenyum dengan energi dari menjaga lingkungan. Jika dihubungkan dengan unsur seni rupa yang ada secara visual terdapat beberapa bagian dan kajian sebagai berikut :

a) Warna. Secara visual poster ini didominasi dengan warna hijau, hijau adalah warna yang memberi kesan damai, kesejukan, merupakan simbol dari alam, keberuntungan, dan kesehatan. Karena itu elemen apapun jika dikombinasikan dengan hijau akan terlihat menarik membawa suasana sejuk.

b) Bentuk. Poster ini mengambil bentuk dari beberapa obyek seperti bumi, manusia, dan daun. Ketika dilihat dari ukuran bentuk bumi yang yang kecil dibanding manusia terlihat metafora yang jauh berbeda ini menandakan atau mempunyai makna bahwa manusia dapat dengan mudah menjaga dunia dengan cara penghijauan dan masa depan bumi berada ditangan manusia. Bumi di atas manusia menandakan menjaga bumi itu penting, seakan menegaskan keutamaan dari keseimbangan di bumi ini dengan menjaganya melalui penghijauan.

c) Ruang. Ruang pada poster memiliki ruang yang cukup luas untuk penyesuaian jarak antara tanda satu dan yang lainnya.

d) Gelap terang. Poster ini memiliki unsur gelap terang yang cukup relevan dan memiliki sinergi yang utuh terhadap visualisasi gambar bentuk yang ada. Ada beberapa ruang yang dibiarkan kosong dengan warna yang cerah untuk memberi jarak dari satu obyek ke obyek lainnya, bermaksud menceritakan dunia ini luas, masa depan yang cerah jika kita dapat menjaga lingkungan.

e) Tekstur. Poster ini memiliki tekstur yang cukup lembut aksen warna perpaduan hijau dengan beberapa warna yang kontras terlihat poster seperti hidup. Tekstur poster ini lebih mengutamakan dampak postif dari penghijauan.

f) Tipografi atau bentuk huruf .Pada tulisan "Green for better Life" disini menggunakan font Janda Manatee yang sudah dipertebal agar dapat terbaca orang banyak. Pengambilan font tersebut juga bertujuan menenjukan kelembutan dari warna di belakang backgroundnya

\section{Makna Konotasi}

Poster penghijauan ini memeliki berbagai penafsiran, berikut penjelasan mengenai beberapa bentuk ilustrasi yang sudah termuat di dalam poster yakni sebagai berikut :

a. Ilustrasi Manusia dengan mimik wajah bahagia menandakan bahwa menunjukan keadaannya sedang bahagia 
b. Ilustrasi bumi di atas kepala yang dihadirkan oleh Nirvana Damar mengkomunikasikan tentang betapa pentingnya dan di utamakan bumi untuk di jaga semua orang.

c. Ilustrasi daun menandakan bahwa simbol komponen yang hidup dan tumbuh. Bermakna mendorong untuk tetap tumbuh, hidup dan berkembang dengan semangat dan energi yang tetap segar.

Secara garis besar poster ini memiliki makna atau simbol bahagia dan rasa nyaman jika kita dapat menjaga lingkungan. Hal yang mendasar dalam poster ini adalah untuk memberitahukan pentingnya menjaga lingkungan hidup agar bumi tetap indah dan nyaman. Dalam poster terdapat tagline "Go Green for better Life" merupakan ungkapan deskripsi serta pemaknaan dari baiknya penghijauan itu sendiri. Tagline ini bertujuan untuk memberikan pemahaman kepada semua orang tentang dampak positif penghijauan.

Simbol atau makna filosofi poster mewakili beberapa yaitu Kebahagiaan, Kebangkitan, Keindahan, Kesenangan, Penghijauan, Kepedulian, Terang, Kesejukan, Bersemangat, Kepedulian, Kehidupan, Lingkungan dan simbol regenerasi.Kata - kata diatas sedikit menggambarkan pemaknaan dari beberapa symbol yang termuat di dalam karya poster berdasarkan penalaran semiotika dan retorika desain. Dilihat dari sisi retorika desain dan visual terdapat metafora antara gambar manusia dan bumi berada di atas kepala. Hal ini memberikan makna bahwa kehidupan bumi tergantung dari bagaimana manusia merawatnya. Majas atau retorika desain hiperbola, dimana ukuran manusia yang termuat di dalam poster sangatlah besar, itu menandakan bahwa manusia penentu atau penopang kehidupan bumi jika perduli terhadap lingkungan. Poster ini sudah cukup baik secara konsep untuk berkontribusi menyampaikan pesan visual terhadap masyarakat terntang pentingnya untuk peduli akan penghijauan. Namun adanya kurang sesuai tanda obyek orang yang disajikan pada poster, ketika dikaitkan dengan tema penghijauan. Konklusi dari semua pemaparan saya diatas adalah pentingnya kita sebagai masyarakat untuk peduli terhadap lingkungan sekitar salah satunya dengan cara penghijauan agar bumi ini dapat juga di nikmati oleh generasi yang akan datang.

\section{b. Logo Serangi Soap}

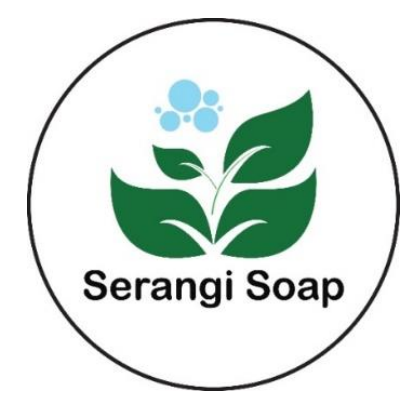

Gambar 3. Logo Karya Angga Pradana Putra (Dokumentasi: Ernawati, 2019)

\section{Makna Denotasi}

Logo terdiri atas busa berwarna biru daun berwarna hijau dengan typografi Serangai Soap pada bidang lingkaran. Peletakan center pada bidang lingkaran dengan susunan tiga tanda. Jika dihubungkan dengan unsur desain yang ada secara visual terdapat beberapa bagian dan kajian sebagai berikut :

Secara visual logo ini didominasi dengan warna hijau, karena hijau sendiri adalah warna yang memberi kesan alami dan kesegaran namun juga elegan. Logo Serangi Soap alami diberi aksen warna Biru muda menyala pada icon Butiran gelembung (busa), ini mempunyai kesan bahwa masih ada kesan kesejukan dan kebersihan atau murni suci, dipadukan dengan warna hijau bisa membawakan arti alami dan kesejukan saat warna itu dikombinasikan. Tipografi "Serangi Soap" disini menggunakan font Arial tebal yang mampu menjelaskan nama produk degan jelas.

\section{Makna Konotasi}

Penyampaikan logo disini mempunyai arti sabun yang harum dan berbusa dengan keunggulan dari logo sabun ini yang dapat menerapkan jarak, kualitas rasa, dan mudah dijangkau oleh semua kalangan serta mudah diingat.Logo Serangi Soap ini memiliki penafsiran yang cukup kompleks, dan bersifat mimesis. Ilustrasi dari Stilasi Daun kemangi dengan bentuk daun yang masih muda sebagai representasi dari kesejukan dan kesegaran. Tanda visual busa yang berada di atas daun kemangi mengkomunikasikan untuk pemaknaan berbusa atau kesegaran.

Logo ini memiliki muatan dengan komposisi warna yang menyejukan. Ilustrasi daun kemangi yang berkolaborasi dengan icon busa yang seolah-olah logo ini membawakan makna kesegaran dan keharuman. Komposisi bentuk daun kemangi dan busa secara struktural kurang menyatu, kesan dari sabun berbahan kemangi dengan busa melimpah kurang terwakili secara visual. Bentuk icon gelembung busa secara aspek kebentukan belum tersampaikan mengingat konsep karya berupa mimesis atau peniruan bentuk.

\section{c. Poster layanan Iklan Masyarakat}

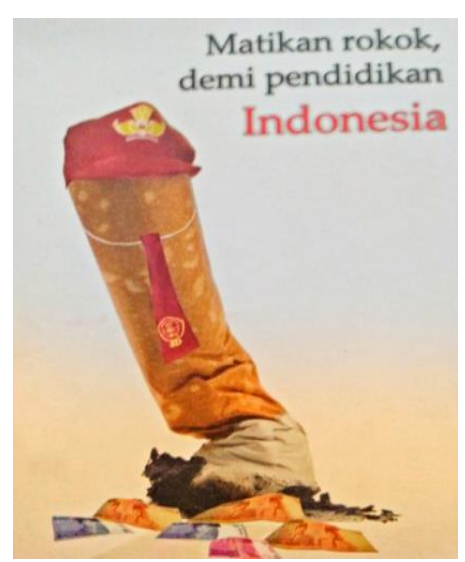

Gambar 4. Poster Iklan layanan Masyarakat Karya Edytha Jivi Mahendra Yogaswara (Dokumentasi : Ernawati, 2019) 


\section{Makna Denotasi}

Secara visual karya poster ini terlihat sangat simple dan mudah untuk dipahami dengan komposisi warna yang menyala. Obyek visualisasi merupakan ilustrasi batang rokok mati yang memakai sebuah topi dan dasi seragam untuk siswa tingkat SD, dengan beberapa lembaran uang di depan ilustrasi rokok. Jika dihubungkan dengan unsur seni rupa yang ada secara visual terdapat beberapa bagian dan kajian sebagai berikut :

a. Warna. Secara visual poster ini didominasi dengan warna orange, karena wana orange memberikan kesan semangat, yang dimana rasa semangat ini kita gunakan untuk memberikan pesan agar dapat meminimasilir para generasi muda kita termasuk para pelajar untuk berhenti merokok.

b. Bentuk. Poster ini memiliki bentuk yang tidak beraturan, jika dilihat dari ukuran bentuk putung rokok terlihat metafora yang jauh berbeda ini menandakan atau mempunyai makna bahwasanya sudah saatnya generasi para pelajar yang ada disekitar kita mengurangi bahkan stop tidak merokok lagi.

c. Ruang. Poster ini memiliki ruang yang cukup sempit, dimana ukuran putung rokok lebih besar dari lembaran uang yang berada dibawahnya, seolah-olah ilustrasi putung rokok itu terlihat seperti raksasa yang sedang berdiri di bawah banyaknya lembaran uang.

d. Tipografi atau bentuk huruf. Tulisan "Matikan rokok demi pendidikan indonesia"menggunakan font times new roman yang sudah dengan cetakan tebal.

\section{Makna Konotasi}

Poster ini menggambarkan peringatan dan informasi terhadap pelajar generasi muda tentang bahaya rokok untuk kesehatan. Metafora rokok sebagai api yang melalap habis kekayaan. Pesan moral bahwa merokok hanyalah kesia-siaan. Poster bahaya merokok ini memeliki banyak penafsiran, berikut penjelasan mengenai beberapa bentuk ilustrasi yang sudah termuat di dalam poster :

a. Ilustrasi putung rokok yang memakai dasi dan topi menandakan atau memiliki makna bahwa putung rokok tersebut menggambarkan seorang pelajar. Retorika visual ini berupa metafora yaitu perbandingan tanda rokok dengan manusia.

b. Ilustrasi gambar banyaknya lembaran uang yang ada dibawah putung rokok memiliki sebuah makna, yang dimana mengartikan banyaknya lembaran uang yang ada dalam poster akan sia- sia jika hanya digunakan untuk merokok. Sama saja kita membakar uang tersebut dengan hal yang sia-sia.

Secara garis besar poster ini memiliki makna untuk mengajak generasi muda terutama para pelajar untuk berhenti merokok. Judul "Matikan Rokok untuk Pendidikan" merupakan langkah yang diambil pencipta poster sehubungan dengan fenomena yang begitu kompleks yang ada disekitar kita. Sebuah poster yang memiliki makna ajakan untuk para pelajar stop merokok karena merokok bukan hanya merusak kesehatan tapi juga membuang uang dengan sia-sia. Hal yang mendasar dalam poster ini adalah untuk mengkampanyekan pentingnya menjaga kesehatan dan bentuk protes terhadap peredaran rokok di kalangan pelajar. Simbol atau makna filosofi poster ini tentang Ajakan, Himbauan, Kehancuran, Kepedulian, Kerugian, pentingnya Kesehatan, Rasa Empati dan Simpati, Pendidikan, Harapan dan Moral. Poster ini sudah cukup baik akan tetapi masih mempunyai sisi kelemahan yaitu pada bagian warna background yang kurang menarik, secara kontekstual poster ini sudah cukup baik karena sudah menyampaikan pesan visual terhadapa masyarakat terhadap pentingnya mematikan rokok demi pendidikan di negara kita.

\section{d. Kolase sebagai Media Informasi tentang Narkoba}

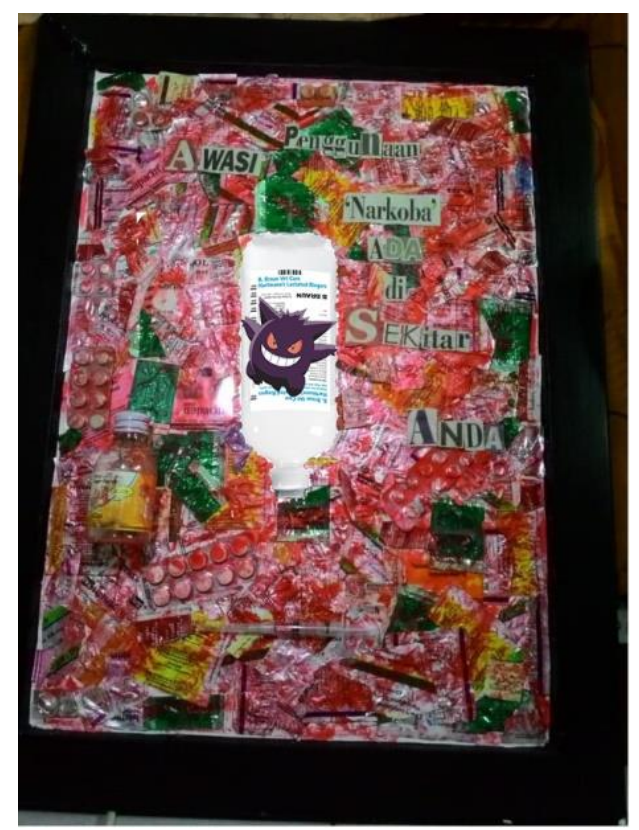

Gambar 5. Kolase Tentang

Informasi Narkoba

Karya Merlyn N.

Ukuran $70 \mathrm{~cm}$ x $50 \mathrm{~cm}$

\section{Makna Denotasi}

Secara visual karya kolase ini terlihat menarik dengan komposisi warna merah yang menyala. Obyek botol infus yang sudah diberi tanda monster yang menakutkan. Kolase ini menghimbau masyarakat agar waspada akan penggunaan obat. kolase ini didominasi warna merah, sehingga memberi kesan menakutkan, diibaaratkan warna darah. Kolase ini memiliki bentuk yang tidak beraturan. Jika dilihat dari ukuran infus dan botol suntik ini menggambarkan tanda indeksikal yaitu tentang sebab dan akibat dari jangka panjang pemakaian obat tanpa pengawasan. 


\section{Makna Konotasi}

Kolase memiliki penafsiaran, mengenai beberapa bentuk tanda sebagai illustrasi yang sudah ada didalam kolase, yaitu: Botol infus yang diberi gambar monster memiliki makna bahwa gambar ini menakutkan, berbagai kemasan obat sebagai latar dibelakang menandakan bahwa obat tidak hanya bisa menyembuhkan tapi bisa juga berbahaya.

Kolase ini memiliki makna atau simbol menakutkan dan menyeramkan. Sebuah kolase yang memiliki makna berbahaya sebagai bahan pembelajaran untuk kita akan pentingnya pengawasan penggunaan obat yang baik agar dapat hasil yang baik juga. Kolase cukup baik dari bentuk penyajian visual akan tetapi masih berantakan dari sisi struktur pentaan obyek atau tanda. Kolase ini mengkounikasikan pesan visual kepada masyarakat terhadap pentingnya mengawasi penggunaan obat yang baik. Kolase ini sudah sesuai dengan tema. Pesan dari karya tersebut tentang pentingnya pengawasan dalam penggunaan obat. Selain itu desainer tampaknya,memiliki tujuan untuk memberi wawasan kepada masyarakat agar lebih paham akan bahaya yang dapat ditimbulkan dari obat yang ada.

\section{e. Logo Kemasan Makanan}

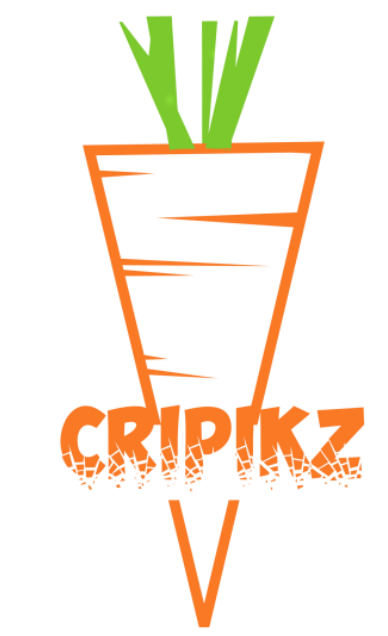

Gambar 6. Logo Kemasan Karya Choirul dwi Cipto

\section{Makna Denotasi}

Logo ini terdiri atas tanda visual sayuran wotel dengan warna orange dan tulisan brand produk yaitu Cripikz. Secara visual logo ini didominasi dengan warna sekunder orange yang merupakan kombinasi antara warna merah dan kuning. Warna orange memberi kesan hangat dan bersemangat serta merupakan symbol dari petualangan, optimise, percaya diri, dan kemampuan dalam bersosialisasi. Warna orange adalah peleburan dari warna merah dan kuning yang sama-sama memberi efek yang kuat dan hangat. Selain itu pada logo ini juga terdapat sentuhan warna hijau. Warna hijau disini juga melambangkan kehidupan dan tabah dalam menghadapi masalah. Warna hijau memiliki sifat menyegarkan, membangkitkan energy, memberikan efek menenangkan, menyejukkan, menyeimbangkan emosi kita, memberikan rasa bahagia dan rasa percaya diri.

Bentuk logo didominasi dengan segitiga yang dijadikan satu menjadi sebuah bentuk wortel. Untuk segitiga sendiri bermakna, memnjadi suatu penunjuk arah, untuk itu kesan yang timbul adalah pencapaian tujuan. Bentuk ini dapat menyimbolkan stabilitas namun dapat pula sebaliknya.Ruang logo ini memiliki ruang yang cukup luas dikarenakan hanya ada sebuah bentuk wortel dalam logo tersebut, yang menandakan logo tersebut terlihat sangat simple. Tekstur Logo ini bisa dikatakan bertekstur keras dikarenakan bentuknya yang didominasi oleh garis lurus. Tipografi

Tipografinya menggunakan font obelix pro broken, yang memilki efek seperti pecahan pecahan guna penyesuaian dengan produk yang dijual dan logo yang dibuat.

\section{Makna Konotasi}

Ikon utama dari logo ini yaitu gambar wortel. Wortel termasuk kelompok sayuran yang merupakan tanaman holtikultura, tanaman yang berbentuk rumput, batangnya pendek dan akar tunggangnya berubah bentuk dari fungsinya menjadi umbi bulat panjang yang dapat dimakan, umbi wortel ini berwarna kuning sampai kemerah merahan karena kandungan karotenoidnya yang tinggi. Terlepas dari pada manfaat dari wortel, Pemaknaan yang diungkapkan dari wortel ini tentang penyampaian bahan pokok yang digunakan untuk makanan ringan supaya sebuah makan ringan dapat dipasarkan dengan baik dan mempunyai daya tarik tersendiri untuk konsumen. Tanda pada logo tentang rasa enak dan renyah produk makanan. Logo cukup menarik dan simpel, Namun kurang mengkomunikasikan tentang bentuk dari isi makanan.

\section{f. Logo Museum Mpu Tantular}

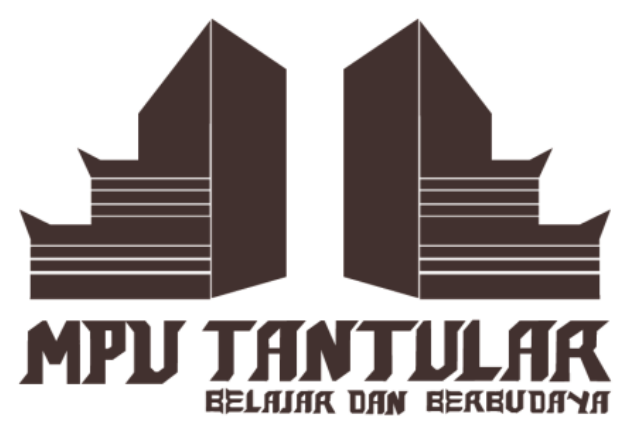

Gambar 7. Logo Museum Mpu Tantular sidoarjo Karya Syahrul Romadhon

\section{Makna Denotasi}

Secara visual logo museum mpu tantular ini terlihat autentik dan kokoh namun tidak mengurangi nilai keasliannya.Ikon logo museum mpu tantular ini 
sebagai gerbang atau land mark museum mpu tantular. Ikon merupakan adaptasi dari bagian gerbang masuk museum mpu tantular Sidoarjo. Jika dihubungkan dengan unsur jaman kerajaan yang ada secara visual terdapat beberapa bagian dan kajian sebagai berikut :

a. Warna. Secara visual logo ini didominasi dengan warna cokelat tua. Warna cokelat pada logo museum mpu tantular terkesan autentik dan mengandung unsur sejarah yang kental. Warna cokelat tua mengandung unsur alami seperti warna batu, kayu dan warna tanah di Indonesia, dan kita semua tahu bahwa di bawah tanah berwarna cokelat tua yang kita pijak sekarang, masih banyak artefak atau candi peninggalan kerajaan jaman dahulu di Indonesia.Warna cokelat tua mengandung unsur alami seperti tanah, batu, dan kayu. Gapura kerajaan dan candi pada jaman dahulu hampir keseluruhan badan candi dibuat dari bahan tanah, batu dan kayu.

b. Bentuk. Logo ini memiliki dua sisi yaitu kanan dan kiri yang simetris. Terlihat seperti gapura atau pintu gerbang untuk memasuki suatu kawasan.Garisgaris yang terdapat pada logo museum mpu tantular memberi kesan tidak monoton. Bentuk lancip pada sudut logo mewakili unsur kerajaan kuno di Indonesia, khususnya di pulau Jawa.

c. Ruang. Logo ini memiliki ruang yang lebar pada bagian tengah, memberi pesan terbuka bagi siapa saja yang ingin berkunjung dan belajar sejarah di museum mpu tantular Sidoarjo. Terdapat ruang sempit memanjang yang disebut garis.

d. Tipografi atau bentuk huruf. Tulisan "MPU TANTULAR" dengan mengadopsi dari bagian sudut logo memberikan sinergi akan kesinambungan antara logo gram dan logo type.

\section{Makna Konotasi}

Logo ini menggambarkan salah satu sejarah kerajaan di Indonesia. Dapat dilihat dari bentuk logo yang menggambarkan sebuah gapura kuno jaman kerajaan dahulu.Garis-garis, dan ujung lancip yang menjadi aksen pada logo tersebut terlihat kaku dan berani. Logo museum mpu tantular ini memiliki banyak penafsiran, berikut penjelasan mengenai beberapa bentuk vector yakni, Penggambaran sejarah kerajaan di Indonesia. Dapat dilihat dari bentuk logo yang menggambarkan sebuah gapura kuno jaman kerajaan dahulu, Sudut logo lancip yang menjadi aksen pada logo museum mpu tantular memiliki makna sebagai bentuk teritorial atau daerah kekuasaan pada era kerajaan. Ruang sempit memanjang pada bagian badan logo yang disebut garis itu memiliki makna atau interprestasi sebagai jantungnya orang seni rupa.kita tau orang orang jaman dahulu kesehariannya tidak lepas dari unsur kesenian yang kental.Garis menjadi elemen rupa sebagai gambaran tradisi orang terdahulu menggunakan garis sebagai media ekspresi senirupa di gua-gua.

Hal yang paling mendasar pada penciptaan logo untuk museum mpu tantular Sidoarjo ini adalah untuk memberikan identitas wajah museum agar semakin dikenal di berbagai daerah luas, agar adik-adik generasi bangsa tidak malas untuk berkunjung ke museum mpu tantular dan mengulik sejarah-sejarah yang terkandung pada peninggalan kerajaan dan budaya Indonesia pada jaman dahulu.

Pada logo museum mpu tantular terkandung tagline "Belajar dan Berbudaya", sampai sini sudah dapat dipahami bahwa dalam logo dan tagline sangat kuat hubungannya dengan identitas museum mpu tantular. Belajar = datang ke museum untuk menggali sejarah yang terkandung pada koleksi benda-benda kuno peninggalan jaman kerajaan dahulu, dan menerapkan pada ilmu pengetahuan social. Berbudaya $=$ kita diajarkan berbudaya untuk menguatkan identitas sebagai orang Indonesia yang budayanya diturunkan dari pendahulu pada masa kerajaan. Belajar dan berbudaya kita terapkan pada kehidupan berbangsa dan bernegara di Indonesia. Logo museum mpu tantular memiliki arti dan makna yang kuat terhadap nama dan isi di museum mpu tantular, dan memberikan nilai sejarah pada unsur logo yang disajikan.

\section{KESIMPULAN}

Makna yang dimuat pada setiap karya desain visual yang disajikan adalah pesan yang disampikan pada khalayak yang telah ditentukan dalam bentuk tanda visual. Secara garis besar dari karya yang disajikan tanda dapat dilihat dari dua aspek, yaitu tanda yang terlihat oleh panca indera berupa bentuk visual dan makna tanda untuk dikomunikasikan.Tanda visual dilihat dari cara penggambarannya baik secara ikonis, indeksikal maupun simbolik. Makna yang dikomunikasikan tanda dapat dijelajah dengan penafsiran berdasarkan konsep keilmuan yang dihubungkan dengan mitos ataupun budaya. Visual yang dihadirkan bersifat similarity atau peniruan bentuk dari kenyataan. Kajian semiotika sebagai metode dalam penelitian, khususnya dalam bidang desain komunikasi visual cukup relevan, karena ada kecenderungan untuk memandang visual sebagai wacana sosial. Mengingat karya desain visual memiliki tanda kombinasi antara verbal dan visual berupa tandatada tertentu serta makna yang dimuat didalamnya, maka penekatan semiotika Roland Barthes sebagai teori untuk analisis pada karya desain komunikasi visual layak untuk diterapkan secara proaktif sesuai dengan konteksnya.

\section{DAFTAR PUSTAKA}

Barthes, Roland.(2007), Membedah Mitos-mitos Budaya Massa: Semiotika atau Sosiologi Tanda, Simbol dan Representasi, Cetakan Pertama, Terjemahan oleh Ikramullah Mahyuddin, Jalasutra: Yogyakarta.

Barthes, Roland. (2009), Mitologi, Cetakan Ketiga, Terjemahan oleh Nurhadi dan A. Sihabul Millah, Kreasi Wacana: Yogyakarta. 
Budiman, Kris. (2011), Semiotika Visual: Konsep, Isu, dan Problem Ikonisitas, Jalasutra: Yogyakarta

Creswell, John w.(2014), Research Design, Qualitative, Quantitative, and Mixed Methods Approaches atau Research Design, Pendekatan
Metode Kualitatif, Kuantitatif, dan Campuran, terjemahan Achmad Fawaid \& Rianayati Kusmini. (2016), Pustaka Pelajar, Yogyakarta. Piliang, Yasraf A. (2012), Semiotika dan Hipersemiotika: Gaya, Kode dan Matinya Makna, Matahari: Bandung. 